DOI:

http://dx.doi.org/10.15448/1983-4012.2018.2.30989

\title{
EXERCÍCIOS FILOSÓFICOS EM EPICTETO
}

Philosophical Exercises in Epictetus

\author{
Diogo da Luz *
}

Resumo: O presente artigo trata do pensamento de Epicteto pelo viés do exercício (áskēsis), ou seja, por meio de práticas que conduzem ao aperfeiçoamento de quem elege para si o ofício de filósofo. Para tal, inicialmente esclarecemos o que significam os exercícios na filosofia antiga, tendo como subsídio as teses de Pierre Hadot. Logo depois, exploramos seis exercícios que consideramos centrais para o filósofo de Nicópolis, contextualizando com os ensinamentos que estão envolvidos e descrevendo as principais características de seu método. Por fim, defendemos que a importância deste artigo está em esclarecer a áskēsis em Epicteto de maneira a evitar possíveis anacronismos.

Palavras-chave: Epicteto, Exercício, Áskēsis, Desejo, Proaíresis.

\begin{abstract}
This article deals with Epictetus' thought through the exercise bias (áskēsis), that is, through the perfectioning practices of those who choose the office of philosophy. In order to do so, we first clarified what exercises in ancient philosophy mean, based on the theses of Pierre Hadot. Continuing, we explore six exercises considered central to the philosopher of Nicopolis, contextualizing with the teachings involved and describing the main characteristics of his method. Finally, we argue that the importance of this article lies in clarifying the áskēsis in Epictetus in order to avoid possible anachronisms.
\end{abstract}

Keywords: Epictetus, Exercise, Áskēsis, Desire, Proaíresis.

\footnotetext{
* Mestre em Filosofia pela Pontifícia Universidade Católica do Rio Grande do Sul (PUCRS). Membro do Grupo de Pesquisa Pórtico de Epicteto e coeditor da Revista Pórtico de Epicteto - https://seer.ufs.br/index.php/Epict.
}

\begin{tabular}{|c|c|c|c|c|c|}
\hline intuitio & $\begin{array}{c}\text { ISSN } \\
1983-4012\end{array}$ & Porto Alegre & Vol.11 $-\mathrm{N}^{\circ} .2$ & $\begin{array}{c}\text { Dezembro } \\
2018\end{array}$ & p.17-33 \\
\hline
\end{tabular}




\section{Considerações Iniciais}

Em seu livro Exercícios espirituais e filosofia antiga, Pierre Hadot defende que a filosofia antiga não pode ser tomada somente como uma forma de racionalidade especulativa nem mesmo como uma abordagem teórica que seja desvinculada da prática. Pelo contrário, a filosofia para os antigos estava estreitamente ligada à maneira de vida. É nesse sentido, por exemplo, que Platão afirma que aqueles que se dizem filósofos, mas que não escolhem o gênero de vida filosófico apenas colocam um verniz exterior em suas opiniões superficiais ${ }^{1}$. A filosofia para os antigos, portanto, não é apenas exposição de teorias, pois isso não é mais do que somente uma abordagem superficial. Ela envolvia antes de tudo a escolha por uma forma de vida, e aqueles que não prezaram por isso foram inclusive criticados:

Todas as escolas denunciaram o perigo que corre o filósofo se imagina que seu discurso filosófico pode bastar-se a si mesmo, sem estar de acordo com a vida filosófica [...]. Tradicionalmente, os que desenvolvem um discurso aparentemente filosófico, sem procurar pôr sua vida em relação com o seu discurso e sem que seu discurso emane de sua experiência e de sua vida, são denominados "sofistas" pelos filósofos $[\ldots]^{2}$.

Essa abordagem da filosofia como modo de vida se faz ainda mais evidente nas escolas filosóficas do período helenístico. Ao relacionar a arte de filosofar com a arte de viver, os filósofos estoicos, céticos, cínicos e epicuristas colocaram o bem-estar psicológico como uma meta a ser alcançada por aquele que busca a sabedoria. Tal ênfase fez com que alguns chamassem essas escolas filosóficas de seitas (haireseis), uma vez que elas implicavam em uma espécie de conversão à vida filosófica ${ }^{3}$. Nesse sentido, como diz Hadot, a conversão deve ser entendida a partir do envolvimento em uma doutrina por meio de determinadas práticas que conduzam ao que se espera de um filósofo:

O filósofo vive assim num estado intermediário: não é sábio, mas não é não sábio. Ele está, pois, constantemente cindido, entre a vida não filosófica e a vida filosófica, entre o domínio do habitual e do cotidiano e o domínio da consciência e da lucidez. Na medida em que ela é prática de exercícios espirituais, a vida filosófica é um desenraizamento da vida cotidiana: ela é uma conversão, uma mudança total de visão, de estilo de vida, de comportamento ${ }^{4}$.

\footnotetext{
${ }^{1}$ PLATÓN. Carta VII. In: Diálogos VII (Dudosos, Apócrifos, Cartas). Madrid: Editorial Gredos, 1992. 340c-d.

${ }^{2}$ HADOT, P. O que é filosofia antiga? Trad. Dion Davi Macedo. 6 ed. São Paulo: Loyola, 2014. p. 252.

${ }^{3}$ DIÔGENES LAÊRTIOS. Vidas e doutrinas dos filósofos ilustres. Trad. Mário da Gama. Brasília: Universidade de Brasília, 2008. p. 17. (I, 20).

${ }^{4}$ HADOT, P. Exercícios espirituais e filosofia antiga. Trad. Flávio Fontenelle Loque, Loraine Oliveira. São Paulo: É Realizações, 2014. p. 58. (Coleção Filosofia Atual)
}

\begin{tabular}{|c|c|l|l|c|c|}
\hline intuitio & $\begin{array}{c}\text { ISSN } \\
1983-4012\end{array}$ & Porto Alegre & Vol.11- $\mathrm{N}^{\mathrm{o} .2}$ & $\begin{array}{c}\text { Dezembro } \\
2018\end{array}$ & p.17-33 \\
\hline
\end{tabular}


Do filósofo são esperadas determinadas condutas, comportamentos relacionados à doutrina da sua escola, de forma que isso concretize o corpus teórico do que se defende. Para isso é necessário não só defender determinados argumentos, mas também exercitar-se em determinadas práticas que se alinhem à proposta filosófica defendida. Na verdade, uma coisa implica a outra, ou seja, a sustentação argumentativa se relaciona com os próprios exercícios, pois a filosofia envolve não só a defesa de uma visão de mundo, mas também uma postura e um envolvimento com o mundo. A argumentação filosófica ganha respaldo na vivência, na encarnação daquilo que se defende; e pelo inverso igualmente se chega ao mesmo objetivo, pois a vivência em determinada forma de vida também se respalda em teorias filosóficas.

Contudo, no início, a adaptação a uma vida filosófica não é uma coisa fácil. Epicteto estava ciente de que a adaptação a uma vida em conformidade com os preceitos estoicos se faz difícil para aqueles que ainda estão em formação. Por isso os exercícios são importantes, pois é através deles que os ensinamentos filosóficos começam a se tornar cada vez mais presentes na vida dos estudantes. É por meio de determinadas práticas que o indivíduo se equipa para enfrentar as opiniões leigas referentes aos verdadeiros bens a serem buscados. Nesse sentido, nas Diatribes 5 encontramos o seguinte excerto:

\begin{abstract}
Mas forçosamente serás levado de um lado a outro pelos leigos ( $\tau \tilde{\omega} v$ i $\delta$ $\omega \tau \tilde{\omega} v)$. E então por que eles são mais fortes que vocês? Porque eles afirmam essas porcarias como suas opiniões enquanto vocês dizem lindezas da boca para fora. Por isso são coisas sem força, mortas; é de dar asco ouvir suas exortações e suas infortunadas virtudes proclamadas de cima a baixo. É assim que os leigos vencem, pois a opinião é forte, a opinião é invencível em tudo. Até que esses conceitos bonitos fiquem mais sólidos em vocês, por segurança, eu os aconselho a condescender com os leigos com precaução. Do contrário, a cada dia tuas anotações escolares se derreterão como cera no sol. Assim, leve os conceitos a alguma parte longe do sol enquanto são moles como a cera. Por isso os filósofos aconselham também a se afastar da pátria, porque os hábitos antigos distraem e não permitem que se comece outro hábito. É que não suportamos quando nos deparamos com pessoas que nos digam: "Veja, fulano agora filosofa, mas antes era assim e assim". Por isso os médicos enviam para outras terras e outros ares os que padecem de uma grande doença, e fazem bem. Dessa forma, introduzam também vocês novos costumes, façam com que se solidifiquem os conceitos, exercitem-se neles ${ }^{6}$.
\end{abstract}

\footnotetext{
${ }^{5}$ Diatribes são discursos de Epicteto que foram anotados por seu aluno Arriano.

${ }^{6}$ EPICTETO. Disertaciones por Arriano. Trad. Paloma Ortiz García. Madrid: Editorial Gredos, 1993. p. 309 (III, XVI, 6-13). (As traduções das Diatribes deste artigo são responsabilidade do autor e foram feitas a partir do original grego e das traduções das seguintes obras: EPICTETO. Disertaciones por Arriano. Trad. Paloma Ortiz García. Madrid: Editorial Gredos, 1993; EPICTETUS. The Discourses as reported by Arrian, The Manual and, Fragments. Trans. W. A. Oldfather. London: Heinemann, 1961. v. 1; EPICTETUS. The Discourses as reported by Arrian, The
}

\begin{tabular}{|c|c|l|l|c|c|}
\hline intuitio & $\begin{array}{c}\text { ISSN } \\
1983-4012\end{array}$ & Porto Alegre & Vol.11- $\mathrm{N}^{\circ} .2$ & $\begin{array}{c}\text { Dezembro } \\
2018\end{array}$ & p.17-33 \\
\hline
\end{tabular}


Percebe-se que Epicteto entende os problemas daqueles que não têm ainda a fortaleza necessária para uma vida filosófica, uma vez que ainda não possuem as opiniões firmemente sustentadas. Para isso, Epicteto aconselha seguir aquilo que outros filósofos já disseram, que é procurar um lugar diferente para tornar mais fácil a introdução de novos hábitos.

É possível perceber também a ênfase dada ao papel das opiniões na vida prática: embora o leigo seja mais ignorante, ele ainda é mais firme devido à convicção em suas opiniões. Por outro lado, o progressor (prokópton), se ainda titubeia, acaba por se revelar mais fraco mesmo já tendo algum contato com a filosofia. Isso ocorre justamente porque ainda lhe falta a firmeza de tratar a filosofia na prática, no cotidiano de suas ações, de forma a fortalecer sua disposição habitual (héxis) nos próprios preceitos filosóficos. A esse aprendiz falta o exercício (áskēsis).

\section{A Educação do Desejo}

Um dos exercícios mais centrais para Epicteto está relacionado à parte que ele considera mais importante no que se refere às paixões: o desejo. Desejo e aversão (órexis e ékklisis) recebem atenção especial enquanto objetos de exercício por corresponderem ao tópico em que se originam as paixões ${ }^{7}$. No Encheirídion ${ }^{8}$ há uma passagem significativa a esse respeito:

Lembra que o propósito do desejo é obter o que se deseja, <e> o propósito da repulsa é não se deparar com o que se evita. Quem falha no desejo é não-afortunado. Quem se depara com o que evita é desafortunado. Caso, entre as coisas que são teus encargos, somente rejeites as contrárias à natureza, não te depararás com nenhuma coisa que evitas. Caso rejeites a doença, a morte ou a pobreza, serás desafortunado. Então retira a repulsa de todas as coisas que não sejam encargos nossos e transfere-a para as coisas que, sendo encargos nossos, são contrárias à natureza. Por ora, suspende por completo o desejo, pois se desejares alguma das coisas que não sejam encargos nossos, necessariamente não serás afortunado. Das coisas que são encargos nossos, todas quantas seria belo desejar, nenhuma está ao teu alcance ainda. Assim, faz uso somente do impulso e do refreamento, sem excesso, com reserva e sem constrangimentos ${ }^{9}$.

Manual, and Fragments. Trans. W. A. Oldfather. London: Heinemann, 1952. v. 2; EPICTETUS. The Discourses of Epictetus, with the Encheiridion and Fragments. Trans. G. Long. London: George Bell \& Sons, 1877).

${ }^{7}$ EPICTETO. Disertaciones por Arriano. Trad. Paloma Ortiz García. Madrid: Editorial Gredos, 1993. p. 270 (III, 2 , 3).

${ }^{8}$ Encheirídion é o Manual de Epicteto. É um resumo das Diatribes elaborado por Arriano.

${ }^{9}$ ARRIANO, F. O Encheirídion de Epicteto. Edição Bilíngue. Trad. Aldo Dinucci e Alfredo Julien. São Cristóvão: Universidade Federal de Sergipe, 2012. p. 17 (II).

\begin{tabular}{|c|c|c|c|c|c|}
\hline intuitio & $\begin{array}{c}\text { ISSN } \\
1983-4012\end{array}$ & Porto Alegre & Vol.11 - No.2 & $\begin{array}{c}\text { Dezembro } \\
2018\end{array}$ & p.17-33 \\
\hline
\end{tabular}


Quando o filósofo relaciona ambos desejo e repulsa às coisas que são nossos encargos (eph' hèmîn), ele está subordinando os dois à naturalidade do lógos do próprio indivíduo. Por outro lado, como para os estoicos há igualmente lógos na natureza, perpassando tudo por meio do pneûma (espírito/sopro) divino, a ação racional do ser humano é também a que se compatibiliza com as leis da natureza. Nesse sentido, Epicteto objetiva proporcionar o ajuste entre desejo e acontecimento, uma vez que a alegria do desejo realizado ocorre quando da conformação aos acontecimentos na cadeia do destino - que é a ordem natural das coisas. Por causa disso, é inútil ter repulsa àquilo que se pode ser destinado a qualquer momento, como a morte e a doença, uma vez que isso ocasionará frustração pelo fato de que é algo que não depende de si, mas de algo externo à própria iniciativa.

Há também nesse trecho uma recomendação importante para quem está a progredir no caminho filosófico: a suspensão do desejo. Essa prática inicialmente pode parecer indicar que Epicteto defende que os desejos sejam reprimidos (dado que o destino é imprevisível ${ }^{10}$ ) para que a relação com os acontecimentos se faça somente por meio do impulso (hormé) e do refreamento (aphormé). Contudo, é preciso notar que a suspensão dos desejos se refere a um estágio da educação do desejo e não à sua totalidade. Não se trata de uma defesa da eliminação dos desejos, mas de suspendê-los enquanto ainda se está longe de alcançar os bens que dependem de si, que são as virtudes. Como diz K. Seddon em Epictetus' Handbook and the Tablet of Cebes, o desejo em Epicteto é "propriamente direcionado somente à virtude"11.

Mas há também outros elementos a serem considerados: em outro momento, Epicteto também afirma que, para não falharmos, devemos entregar nossos desejos aos deuses para que eles os governem.

Se entregas a pobreza e a riqueza ao desejo e à repulsa, então cairás e falharás; se a saúde, serás desafortunado. Isso é igual com os cargos, as honras, a pátria, os amigos, os filhos; em poucas palavras: em tudo que independe da tua preferência ( $\dot{\alpha} \pi \lambda \tilde{\omega} \varsigma \ddot{\alpha} v \tau \imath v \imath \tau \tilde{\omega} v$ $\left.\dot{\alpha} \pi \rho \alpha_{1} \varepsilon \dot{\tau} \tau \omega v\right)$. Coloque-os nas mãos de Zeus e dos demais deuses. Entregue a eles, que eles os governem, que se alinhem com eles. Dessa forma, como seguirás mal? ${ }^{12}$

\footnotetext{
${ }^{10}$ EPICTETO. Disertaciones por Arriano. Trad. Paloma Ortiz García. Madrid: Editorial Gredos, 1993. p. 421 (IV, 7, 7).

${ }^{11}$ SEDDON, K. Epictetus' Handbook and the Tablet of Cebes: guides to Stoic living. New York: Routledge, 2005. p. 224.

${ }^{12}$ EPICTETO. Disertaciones por Arriano. Trad. Paloma Ortiz García. Madrid: Editorial Gredos, 1993. p. 217 (II, 17, 24-26).
}

\begin{tabular}{|c|c|c|c|c|c|}
\hline intuitio & $\begin{array}{c}\text { ISSN } \\
1983-4012\end{array}$ & Porto Alegre & Vol.11 - No.2 & $\begin{array}{c}\text { Dezembro } \\
2018\end{array}$ & p.17-33 \\
\hline
\end{tabular}


Nessa outra recomendação, Epicteto parece defender a entrega do desejo - que é uma coisa que é eph' hèmîn (encargo nosso) - aos deuses, de forma que isso talvez possa ser interpretado como uma alienação de algo pelo qual somos responsáveis. Porém, se observarmos o contexto envolvido, podemos notar que essa "entrega do desejo" corresponde na verdade a uma força de expressão para "alinhamento do desejo", do qual se depreende que não se trata especificamente de uma desresponsabilização pelo que se deseja, mas do reconhecimento de que algo maior serve como guia para o desejo.

\section{A Perspectiva Universal do Cosmos}

O alinhamento dos desejos ao destino é facilitado quando se leva em consideração o exercício de análise dos processos da natureza (que é o mesmo que a providência divina). A perspectiva universal do cosmos faz compreender que os acontecimentos estão relacionados a algo maior do que qualquer pretensão vã de uma singela parte da natureza, ou seja, a algo maior do que qualquer iniciativa individual de controle sobre o que está para além de suas possibilidades. Essa análise serve para "colocar o indivíduo no seu lugar”, para acomodar seus desejos irracionais de controlar aquilo que não lhe cabe. Esse exercício foi muito utilizado por Marco Aurélio em suas Meditações, influenciado, com certeza, pelos ensinamentos de Epicteto ${ }^{13}$. Como podemos ver, há uma clara relação entre ambos:

Epicteto:

[A divindade] submeteu ao giro universal a terra, as roupas, a casa, os filhos, a mulher. Por que, então, luto contra a divindade? Por que quero o que não se deve querer, ter a qualquer preço o que não me foi dado? E então, como? Como me foi dado e na medida do possível, pois o que ela dá, ela tira. Então, por que me oponho? Não digo que serei tonto tentando forçar o que é mais forte, mas ainda mais que isso: injusto ${ }^{14}$.

\section{Marco Aurélio:}

Toda natureza satisfaz-se com seguir bem o seu caminho. A natureza racional segue bem o seu caminho quando, nos pensamentos, não assente ao falso e ao dúbio; nos impulsos, tende apenas para as obras do bem comum; nos desejos e aversões, atém-se ao que

\footnotetext{
${ }^{13}$ HADOT, P. La Ciudadela Interior. Introducción a las Meditaciones de Marco Aurelio. Trad. Maria Cucurella Miquel. Salamanca: Alpha Decay, 2013. p. 55.

${ }^{14}$ EPICTETO. Disertaciones por Arriano. Trad. Paloma Ortiz García. Madrid: Editorial Gredos. 1993. p. 385. (IV, I, 100-101).
}

\begin{tabular}{|c|c|c|c|c|c|}
\hline intuitio & $\begin{array}{c}\text { ISSN } \\
1983-4012\end{array}$ & Porto Alegre & Vol.11 $-\mathrm{N}^{\circ} .2$ & $\begin{array}{c}\text { Dezembro } \\
2018\end{array}$ & p.17-33 \\
\hline
\end{tabular}


depende de nós, acatando de bom grado tudo que a natureza comum lhe atribui. Porque ela é uma parte desta, como a natureza da folha o é da natureza da planta ${ }^{15}$.

Nesse sentido, retomar sempre essa ideia de que a parte está submetida ao todo é um exercício que ajuda a prevenir as aspirações irracionais, uma vez que traz sempre à mente a consciência da delimitação do campo de ação do indivíduo, que em Epicteto está nos três tópoi: (i) desejo/repulsa, (ii) impulso/refreamento, (iii) assentimento ${ }^{16}$.

\section{Da Consciência Cósmica à Atenção (Prosochế)}

Uma recomendação constante na filosofia antiga e nos estoicos em geral é o foco no momento presente. É o que Hadot relacionou ao sentimento oceânico, que é a capacidade de notar e valorar a beleza do instante em meio ao todo da existência ${ }^{17}$. No estoicismo essa consciência se reflete no amor fati, que é o amor ao destino, o amor ao momento destinado. Em Epicteto isso aparece em uma forma profundamente religiosa através de suas seguidas referências ao lógos divino, bem como por sua gratidão ( $\underline{\text { eucharistía })}$ à Zeus.

O bem-estar com relação ao presente está diretamente associado à compreensão epictetiana de que a vida humana e as coisas a ela relacionadas partem da benevolência divina. Essa ideia, que também pode ser identificada em Crisipo, difere de outras considerações religiosas que tomam os deuses como agentes tanto de coisas boas quanto de coisas más ${ }^{18}$. A eucharistía de Epicteto está na base do otimismo em relação àquilo que acontece, uma vez que, quando se está ciente de que a oportunidade de viver é gratuitamente oferecida, percebe-se que a função na existência nada mais é do que usufruir a vida da melhor maneira possível através da liberdade concedida por Zeus. Em vista disso, relatam Rodrigues e Dinucci:

O simples fato de viver, de se estar no mundo, basta para Epicteto agradecer a honra, o
privilégio de participar do que para ele é um milagre - o milagre da vida! Lembremo-nos
de que quando Epicteto ensinou aquela vez o real significado de se ser um estoico, tinha

${ }^{15}$ MARCO AURÉLIO. Meditações. In: EPICURO - LUCRÉCIO - CÍCERO - SÊNECA - MARCO AURÉLIO. 3. ed. Trad. Agostinho da Silva. São Paulo: Abril Cultural, 1985. p. 547. (VIII, 7). (Grifo nosso)

${ }^{16}$ EPICTETO. Disertaciones por Arriano. Trad. Paloma Ortiz García. Madrid: Editorial Gredos, 1993. p. 270. (III, 2, 1-2).

${ }^{17}$ HADOT, P. A Filosofia como maneira de viver: entrevistas de Jeannie Carlier e Arnold I. Davidson. Trad. Lara Christina de Malimpensa. São Paulo: É Realizações, 2016. p. 22-25.

${ }^{18}$ RODRIGUES, A. C. O.; DINUCCI, A. A eucharistia em Epicteto. In: COSTA, C. L F.; ECCO, C.; FILHO, J. R. F. M. (Org.). Epistemologias da religião e relações de religiosidade. Curitiba: Prismas, 2017. p. 22-26.

\begin{tabular}{|c|c|l|l|c|c|}
\hline intuitio & $\begin{array}{c}\text { ISSN } \\
1983-4012\end{array}$ & Porto Alegre & Vol.11- $\mathrm{N}^{\circ} .2$ & $\begin{array}{c}\text { Dezembro } \\
2018\end{array}$ & p.17-33 \\
\hline
\end{tabular}


a seu favor o testemunho da própria vida. Aquele ancião de pequena estatura física era um gigante no espírito - pois havia transposto muitos daqueles obstáculos que ensinava a sobrepujar, ultrapassar, vencer. Nem o desterro, nem a pobreza, tampouco a velhice ou o fato de ser coxo o impediu de, acima de tudo, e de todas essas circunstâncias, agradecer e ensinar a todos que o ouviam a render incansável e prodigamente graças à virtude.

A teoria epictetiana afirma que a graça divina consiste na dádiva - oferecida igualmente a todos os seres humanos - de uma capacidade de escolha desobstruída e na matéria para que tal capacidade se exercite. Segundo essa visão, o ser humano pode por si mesmo alcançar a serenidade, a felicidade e, consequentemente, ser grato a Deus, sob a condição que desenvolva a capacidade de escolha, livrando-a das falsas opiniões, e que adote uma visão conjunta da realidade, capacitando-o a perceber a Providência nas coisas que tornam possível sua vida e que são matéria para sua escolha ${ }^{19}$.

A vida como uma dádiva é uma consequência do poder divino, e isso é percebido pelo reconhecimento de uma ordem na natureza que ultrapassa o lógos humano. No entanto, enquanto a vida pode ser tomada como positiva sob a perspectiva cósmica, ela não necessariamente se traduz em algo positivo sob a perspectiva individual. Nesse sentido, a consciência cósmica até evidencia a dádiva da vida em seu momento presente, mas ainda não garante o bem-estar nesse momento presente, uma vez que isso já não mais depende da divindade. Para que a vida seja considerada boa de forma completa é necessário que o indivíduo também faça a sua parte e preste atenção às suas opiniões, que é o que depende dele.

A atenção (prosochế) é um exercício importante para Epicteto, sendo inclusive o título de uma de suas Diatribes (IV, 12). Nela o filósofo ressalta que justamente a falta de atenção é o pior de todos os costumes, pois negligenciar a consideração sobre o momento presente implica atrasar para outro momento a própria serenidade ${ }^{20}$. Além do mais, se atenção é necessária a várias artes, por que ela também não seria necessária à arte de viver? Nesse sentido, ele aponta:

O carpinteiro, se não presta atenção, constrói melhor? O piloto, se não presta atenção, conduz o barco de forma mais segura? Das tarefas pequenas, alguma resulta melhor por falta de atenção? Não te dás conta de que, uma vez que deixas livre o pensamento, já não está em tua mão o chamar à compostura, ao decoro, à tranquilidade, mas que fazes tudo o que te ocorre e segues teus apetites?

- A que então devo prestar atenção?

Em primeiro lugar aos universais, tê-los sempre à mão, e sem eles não dormir, não levantar, não comer nem se relacionar com os outros: que ninguém é dono da preferência

${ }^{19}$ RODRIGUES, A. C. O.; DINUCCI, A. A eucharistia em Epicteto, In: COSTA, C. L F.; ECCO, C.; FILHO, J. R. F. M. (Orgs.). Epistemologias da religião e relações de religiosidade. Curitiba: Prismas, 2017. p. 53.

${ }^{20}$ EPICTETO. Disertaciones por Arriano. Trad. Paloma Ortiz García. Madrid: Editorial Gredos. 1993. p. 446. (IV, $12,1-3)$.

\begin{tabular}{|c|c|c|c|c|c|}
\hline intuitio & $\begin{array}{c}\text { ISSN } \\
1983-4012\end{array}$ & Porto Alegre & Vol.11 - No.2 & $\begin{array}{c}\text { Dezembro } \\
2018\end{array}$ & p.17-33 \\
\hline
\end{tabular}


(proaíresis) alheia e que somente nela residem o bem e o mal. Portanto, ninguém é meu dono nem pode conseguir para mim o bem nem me afastar do mal, visto que somente eu tenho esse poder sobre mim mesmo. Quando tiver isso seguro, como poderei inquietarme pelo exterior? Que tirano, doença, pobreza ou obstáculo será temível? ${ }^{21}$

Nesse trecho Epicteto mostra a importância de não descuidar daquilo que ele chama de universais, que são as regras que estão na base de sua teoria: a liberdade e a autonomia da preferência (proaíresis) ${ }^{22}$. A atenção, portanto, é ter sempre em mente essas regras que nunca mudam, sendo por isso utilizáveis em todo e qualquer momento. Atentar para os universais é mantê-los sempre presentes junto consigo, pois não adianta somente reconhecê-los como frutos de raciocínios corretos e bem elaborados, mas também de trazê-los sempre à mente para a consideração das mais diversas circunstâncias. Não basta somente chegar a raciocínios corretos, é necessário se exercitar neles, trazendo-os sempre aos fatos e não os deixar em um plano distante da vida ${ }^{23}$.

\section{O Hábito}

É normal que se tornem habituais as atividades que frequentemente são realizadas. Dessa forma, determinadas reações surgem mais prontamente quando se deparam com situações costumeiras, uma vez que já existem certos hábitos arraigados no sujeito em função de frequentemente agir da mesma maneira. A disposição formada por esses hábitos arraigados os antigos chamavam de héxis, que corresponde a uma condição ou disposição habitual do indivíduo ${ }^{24}$.

${ }^{21}$ EPICTETO. Disertaciones por Arriano. Trad. Paloma Ortiz García. Madrid: Editorial Gredos, 1993. p. 446-447. (IV, 12, 5-9).

22 "Prohaíresis, segundo Bailly (2000), o termo expressa 'a escolha antecipada, a tomada de partido ou o desejo premeditado', adquirindo os sentidos de 'vontade, plano e intenção'. Marcando oposição com anánkē (necessidade), em alguns contextos é vertido por 'livre-arbítrio'. O termo é traduzido como 'moral purpose' por Oldfather (1928); 'choice' por White (1983); 'choix' por Gourinat (1998); e 'albedrío' por García (1995). (ARRIANO, F. O Encheirídion de Epicteto. Edição Bilíngue. Trad. Aldo Dinucci e Alfredo Julien. São Cristóvão: Universidade Federal de Sergipe, 2012. p. $72-73$ [nota 27]).

${ }^{23}$ Como explica Epicteto: "Será que o raciocínio não me convenceu? Mas é que, logo no início, não o coloquei à prova nem escolhi outra coisa; sobre isso leio, escuto, escrevo. Até agora não encontramos nenhum raciocínio mais forte do que esse. Então o que me falta? Será que ainda não me foram arrancadas as opiniões contrárias? Será que as

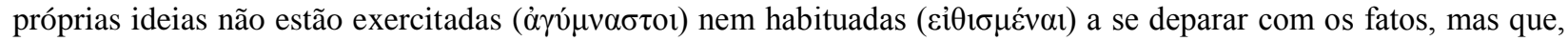
como armas descartadas, estão cobertas de ferrugem e já não posso nem me ajustar a elas? (...) No entanto, nos preceitos $(\theta \varepsilon \omega \rho \eta \dot{\eta} \mu \tau \alpha)$ necessários, a partir dos quais se pode estar sem sofrimentos, sem medos, impassível ( $\dot{\alpha} \pi \alpha \theta \tilde{\eta})$, sem travas, livre, nesses não treino $(\gamma v \mu \nu \alpha ́ \zeta \omega)$ nem pratico $(\mu \varepsilon \lambda \varepsilon \tau \tilde{\omega})$ os cuidados correspondentes a eles". [EPICTETO. Disertaciones por Arriano. Trad. Paloma Ortiz García. Madrid: Editorial Gredos. 1993. p. 416 (IV, 6, 13-17)].

${ }^{24}$ PETERS, F. E. Termos filosóficos gregos: um léxico histórico. Trad. Beatriz Rodrigues Barbosa. 2 ed. Lisboa:

\begin{tabular}{|c|c|c|c|c|c|}
\hline intuitio & $\begin{array}{c}\text { ISSN } \\
1983-4012\end{array}$ & Porto Alegre & Vol.11 $-\mathrm{N}^{\circ} .2$ & $\begin{array}{c}\text { Dezembro } \\
2018\end{array}$ & p.17-33 \\
\hline
\end{tabular}


De acordo com Epicteto, muitas vezes se cai e se recai nas paixões porque a héxis se nutriu das más ações que a alimentaram. A héxis viciada dificulta inclusive o caminho daquele que já está a se exercitar nos preceitos filosóficos, pois ela se moldou anteriormente pelas más ações. Nesse sentido, deve-se cuidar para que ela não seja ainda mais alimentada por ações viciosas, visto que, como afirma o filósofo, isso é o mesmo que acrescentar mais graveto à fogueira $^{25}$.

Devido à dificuldade de alterar a héxis viciada, a mudança de comportamento não ocorre de uma hora para outra, sendo por isso necessários os exercícios. É ingenuidade acreditar que por ouvir ou falar belos argumentos filosóficos se modifica a vida de uma hora para outra. É preciso se exercitar nos preceitos, trazê-los à vida, incorporá-los.

A áskēsis que Epicteto defende se estrutura na mudança da héxis viciada por meio da atividade de habituar-se (ethízein) a um comportamento correto. Nesse caso, para melhor compreender como isso ocorre, é preciso considerar uma observação importante do filósofo: que o remédio para determinado hábito (éthos) reside num hábito contrário (enantíon éthos) ${ }^{26}$. Sendo assim, a mudança para melhor ocorrerá na medida em que o hábito corresponder ao oposto da ação viciosa. Portanto, é dessa maneira que Epicteto defende que uma habituação correta é capaz de tornar o ser humano virtuoso, servindo como um exercício para aquele que quer progredir.

Dado que Epicteto se apoia na tradição do monismo psicológico estoico, a sua descrição de atividade habitual difere de outras que consideram a divisão da alma em partes (racional e irracional). Epicteto trata da alma com um todo, de forma holística, não sendo possível fazer como em Aristóteles, por exemplo, que distingue as virtudes da razão (dianoéticas) das virtudes do condicionamento do desejo (éticas) ${ }^{27}$. O éthos para Epicteto não envolve uma espécie de condicionamento de uma parte irracional, mas é o desenvolvimento do aspecto racional na medida em que este se reflete holisticamente no ser humano. É por isso que Epicteto não admite que as paixões possam ocorrer sem o envolvimento reflexivo da proaíresis, diferentemente de Aristóteles que até as considera como partindo de si pela própria iniciativa (hekousía), mas não

Fundação Calouste Gulbenkian, 1983. p. 105.

${ }^{25}$ EPICTETO. Disertaciones por Arriano. Trad. Paloma Ortiz García. Madrid: Editorial Gredos, 1993. p. 220 (II, 18, $5-7)$.

${ }^{26}$ EPICTETO. Disertaciones por Arriano. Trad. Paloma Ortiz García. Madrid: Editorial Gredos, 1993. p. 137 (I, 27, 4-5).

${ }^{27}$ WOLFF, U. A Ética a Nicômaco de Aristóteles. Trad. Enio Paulo Giachini. São Paulo: Loyola, 2010. p. 42-44.

\begin{tabular}{|c|c|l|l|c|c|}
\hline intuitio & $\begin{array}{c}\text { ISSN } \\
1983-4012\end{array}$ & Porto Alegre & Vol.11- $\mathrm{N}^{\circ} .2$ & $\begin{array}{c}\text { Dezembro } \\
2018\end{array}$ & p.17-33 \\
\hline
\end{tabular}


pela proaíresis ${ }^{28}$. Essa diferença é significativa para se entender o processo de formação do indivíduo virtuoso na filosofia de Epicteto, pois seu ensinamento prima pelo desenvolvimento integral a partir daquilo que proporciona as aretaí (virtudes) propriamente humanas, a saber, o lógos. Nisso Epicteto segue os estoicos antigos, enquadrando-se na seguinte observação de Inwood:

É por isso que a aquisição da virtude [para os estoicos antigos] é essencialmente uma questão de aprendizado, de converter a inconsistente e hesitante opinião sobre o bem em um firme conhecimento que governe sempre a vida. Essa é também a razão pela qual os antigos estoicos acreditavam que a única maneira de tornar os homens melhores era educar a sua razão - e não produzir uma disposição convenientemente obediente em algum poder mais baixo e fundamentalmente não-racional da alma, como Aristóteles fez. ${ }^{29}$

No entanto, dado esse contexto de que para Epicteto toda e qualquer iniciativa envolve a razão, pode-se talvez questionar sua defesa da filosofia enquanto prática. Como ele pode defender que são necessários exercícios para a modificação da conduta? Não bastaria, por exemplo, apenas realmente entender os escritos do estoico Crisipo para ser virtuoso?

Para Epicteto, a filosofia é uma técnica para a vida que requer prática, e esta, por sua vez, envolve fundamentalmente a razão porque se orienta a uma questão propriamente humana. Sendo assim, o que Epicteto ensina é que é preciso se habituar a atuar de uma forma diferente daquela que se atuava antes, pois se deve passar a considerar racionalmente aquilo que não era considerado.

A habituação em Epicteto dá-se pelo processo de habituar/acostumar a si mesmo. Nesse sentido, ela é um processo autônomo pelo qual o próprio indivíduo se torna o responsável

\footnotetext{
${ }^{28}$ KAHN, C. Discovering the Will. In: DILLON, J. M.; LONG, A. A. (Ed.). The Question of "Eclecticism": Studies in Later Greek Philosophy. Berkeley: University of California Press, 1988. p. 239.

${ }^{29}$ INWOOD, B. Ethics and Human Action in Early Stoicism. Oxford: Oxford University Press, 1985. p. 138. Além do mais, ao considerar o reflexo disso no contexto político, é possível constatar que a produção de uma disposição convenientemente obediente pode levar ainda a outros problemas. Como afirma Gross: "Scholars têm largamente negligenciado o papel cumprido pela passividade cristã na história das ciências humanas, particularmente na teoria política. [...] Mas quando nós provocamos as conotações aristotélicas esquecidas desses sermões parlamentares [antes citados], nós percebemos que a passividade cristã é necessária para explicar como a natureza humana pode ser movida em tudo, seja por meio do hábito (segunda natureza), por intervenção divina (supernature), ou por ambos em cooperação. E este é, em parte, o meu propósito aqui: sugerir que a passividade não pode ser facilmente erradicada dos projetos de transformação humana, independentemente de qual possa ser a finalidade política." (GROSS, D. M. The Secret History of Emotion: from Aristotle's Rhetoric to modern brain science. Chicago: The University of Chicago Press, 2006. p. 96).
}

\begin{tabular}{|c|c|l|l|c|c|}
\hline intuitio & $\begin{array}{c}\text { ISSN } \\
1983-4012\end{array}$ & Porto Alegre & Vol.11- $\mathrm{N}^{\circ} .2$ & $\begin{array}{c}\text { Dezembro } \\
2018\end{array}$ & p.17-33 \\
\hline
\end{tabular}


intelectual por suas práticas habituais. É dessa forma, por exemplo, que Epicteto relaciona a habituação a três estágios na luta com as representações:

\begin{abstract}
Em primeiro lugar, [1] não te deixes arrebatar por sua intensidade [da representação], mas diga: 'Espere um pouco, representação ( $\varphi \alpha v \tau \alpha \sigma i ́ \alpha)$; deixa que eu veja quem és e do que tratas, deixa que eu te ponha à prova'. [2] E depois não a deixes avançar pintando o que vier em seguida. Caso contrário, ela te reterá e te levará para onde ela quiser; mas, pelo contrário, (3) introduza tu, por ti mesmo, alguma outra representação bela e nobre e

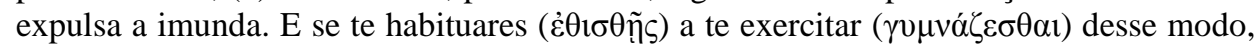
verás que ombros terás, que tendões, que vigor! Por enquanto, somente argumentinhos e nada mais. ${ }^{30}$
\end{abstract}

O tipo de hábito que Epicteto quer despertar em seus alunos é o de analisar as representações, pois é através delas que nos relacionamos voluntariamente com o mundo. A atuação que é eph' hēmîn é aquela intermediada pelas representações (phantasíai). Dessa forma, o que Epicteto pode fazer é no máximo estimular seus alunos a habituarem-se a essa prática, não podendo condicioná-los ao que ele diz ser verdadeiro, dado que isso seria uma tentativa vã de suprimir a liberdade alheia. Submeter os outros a determinadas atividades é no máximo submeter os seus corpos, mas não as suas mentes ou suas preferências. A proaíresis do outro continua livre e autônoma.

A educação que verdadeiramente leva à virtude é aquela que parte de si, de forma livre, desimpedida, que inevitavelmente respeita a formação autônoma da proaíresis.

\title{
5. A Anamnese da Proaíresis
}

Como afirma Gill, em Epicteto é possível identificar um método terapêutico que se desenvolve por meio de conversações que expõem o próprio self a si mesmo ${ }^{31}$. Através de diálogos com claras influências socráticas, o filósofo procura trazer à superfície os anseios, as perturbações e as controvérsias que estão no íntimo de cada um. Dessa maneira, as questões psicológicas se tornam o objeto das considerações filosóficas, pois o âmbito da interioridade é levado para o espaço compartilhado do debate. Através da conversa, o que é interno passa a ser visto pela própria pessoa e, com a ajuda do filósofo-terapeuta, ela passa a exercitar filosoficamente suas questões psicológicas.

${ }^{30}$ EPICTETO. Disertaciones por Arriano. Trad. Paloma Ortiz García. Madrid: Editorial Gredos. 1993. p. 222 (II, 18, 23-26).

${ }^{31}$ GILL, C. The Structured Self in Hellenistic and Roman Thought. New York: Oxford, 2006. p. 389.

\begin{tabular}{|c|c|c|c|c|c|}
\hline intuitio & $\begin{array}{c}\text { ISSN } \\
1983-4012\end{array}$ & Porto Alegre & Vol.11 $-\mathrm{N}^{\circ} .2$ & $\begin{array}{c}\text { Dezembro } \\
2018\end{array}$ & p.17-33 \\
\hline
\end{tabular}


Nessas conversações, Epicteto claramente foca em vincular os ensinamentos da filosofia estoica à vida prática daqueles que o procuram. Tomando a si mesmo como exemplo em algumas ocasiões, ele pretende mostrar que é possível sim viver em conformidade com os preceitos filosóficos, mas que isso implica a busca pelo aperfeiçoamento nos desejos, impulsos e assentimentos (os três tópoi). Ainda assim, Epicteto não se contenta em dar somente o seu exemplo, uma vez que sua terapia envolve mais do que isso: ela corresponde a um método específico que permite relacioná-la à noção ética de bem, sendo que esse bem deve ser percebido por si mesmo, e não "recebido de fora". É por isso que sua terapia de maneira alguma envolve qualquer tipo de mímēsis (imitação) ou prática irrefletida.

A terapia epictetiana se faz não só por meio da análise dos comportamentos/modos de agir (impulsos) ou dos argumentos e raciocínios (assentimentos), mas também por meio da análise dos anseios mais profundos (desejos). Os desejos são de capital importância para o bem-estar psicológico, pois eles são capazes de afetar os demais tópoi (impulso e assentimento). Os desejos são atividades (érga) interiores que não se mostram tão facilmente como os impulsos. No entanto, eles podem ser expostos numa conversa e, a partir disso, pode-se trabalhar filosoficamente sobre eles.

A abordagem filosófica sobre os desejos revela que a busca de Epicteto está para além do que se mostra no impulso ou do que superficialmente se mostra na articulação de meras palavras. Seu objetivo é chegar a algo que está implícito no interior de cada um.

Apesar disso, não é possível dizer que Epicteto restringe sua terapia à questão do desejo, pois, apesar de relevante, ele é somente um dos três tópoi. A ênfase no tópico do desejo apenas indica que Epicteto vislumbrou algo mais profundo do que os estoicos anteriores. O que de fato Epicteto busca está relacionado aos desejos, impulsos e assentimentos, uma vez que todas essas três atividades estão relacionadas à proaíresis.

A proaíresis é uma potência que subsidia as demais atividades numa unidade de atuação, é o que expressa o "eu" que é capaz de desejar, impulsionar e assentir. Nesse sentido, a proaíresis é o que há de mais íntimo em cada um.

Essa percepção de que a proaíresis em Epicteto reúne as funções psicológicas em uma unidade já foi abordada por Kahn, mas seu objetivo com isso foi defender que em Epicteto seria possível encontrar uma noção nova ${ }^{32}$ que posteriormente subsidiaria o conceito de "vontade". De

\footnotetext{
${ }^{32}$ KAHN, C. Discovering the Will. In: DILLON, J. M.; LONG, A. A. (Ed.). The Question of "Eclecticism": Studies
}

\begin{tabular}{|c|c|c|c|c|c|}
\hline intuitio & $\begin{array}{c}\text { ISSN } \\
1983-4012\end{array}$ & Porto Alegre & Vol.11 - No.2 & $\begin{array}{c}\text { Dezembro } \\
2018\end{array}$ & p.17-33 \\
\hline
\end{tabular}


nossa parte, não pretendemos considerar o conceito de proaíresis por esse viés especulativo, mas nos atermos à questão que julgamos mais significativa para os propósitos de Epicteto: a importância da proaíresis em sua função prática, ou mais especificamente, em sua funcionalidade terapêutica.

Em seus diálogos, Epicteto frequentemente menciona os três tópoi, mas também faz questão de trazer à tona a proaíresis. Ela se mostra relevante em basicamente dois sentidos: enquanto liberdade e enquanto posicionamento ou tomada de partido.

A proaíresis enquanto liberdade se faz importante na terapia quando o filósofo mostra aos seus interlocutores que nada nem ninguém pode determinar a preferência alheia, sendo ela um aspecto inviolável no indivíduo. Por mais que se obrigue o corpo, que se tomem as posses ou algo parecido, tais impedimentos sempre se remeterão ao que é externo, não atingindo a capacidade de preferir ou eleger uma coisa em detrimento de outra. Essa inviolabilidade da proaíresis é o que dá a confiança necessária para que, mesmo diante de situações consideradas difíceis, o ser humano possa se manter firme e incorruptível, ciente de sua potência e dignidade.

O sentido da proaíresis enquanto posicionamento ou tomada de partido é outro aspecto importante para a terapia, uma vez que mostra que há sempre a possibilidade de o ser humano se posicionar de modo a se encontrar (na natureza) e ser feliz. Para isso, ele deve tomar o partido do lógos, da virtude, da conformidade consigo e com a natureza. Ao ser humano Zeus entregou uma parte de si, livre, capaz de escolher sem impedimentos ou entraves. É por meio da proaíresis que o ser humano pode encontrar o divino a todo e qualquer momento.

Esses dois aspectos da proaíresis são extremamente importantes para o combate às paixões, pois ambos se relacionam fundamentalmente ao bem do ser humano. Ao ressaltar a proaíresis, Epicteto mostra a importância de se identificar para onde se direciona a preferência nas mais diversas ocasiões, se de fato ao que é preferível (proairetikós) ou ao que é nãopreferível (aproaíreton). Preferir o não-preferível é um erro, pois é relacionar o bem não à virtude, mas àquilo que não depende de nós, ao efêmero, ao material. Tal erro está na raiz de todas as paixões, de todos os desejos mal resolvidos. Por isso, fazer uma anamnese da proaíresis, ou seja, rememorá-la ao realizar conversas filosóficas sobre as questões da alma, é buscar expor os erros e acertos ético-psicológicos mais fundamentais.

in Later Greek Philosophy. Berkeley: University of California Press, 1988. p. 252.

\begin{tabular}{|c|c|c|c|c|c|}
\hline intuitio & $\begin{array}{c}\text { ISSN } \\
1983-4012\end{array}$ & Porto Alegre & Vol.11- No.2 & $\begin{array}{c}\text { Dezembro } \\
2018\end{array}$ & p.17-33 \\
\hline
\end{tabular}




\section{Dizer o que as coisas ou fatos realmente são}

Outra prática recomendada por Epicteto é se referir às coisas como elas de fato são sem lhes atribuir características alheias à sua condição. De fato, muitas paixões surgem quando se considera erroneamente os objetos externos, uma vez que eles devem ser considerados indiferentes. O que deve fazer diferença é a forma como se usa as coisas, e não elas em si mesmas:

Sobre cada uma das coisas que seduzem, tanto as que se prestam ao uso quanto as que são amadas, lembra de dizer de que qualidade ela é, começando a partir das menores coisas. Caso ames um vaso de argila, [diz] que "Eu amo um vaso de argila", pois se ele se quebrar, não te inquietarás. ${ }^{33}$

Ao dizer que se ama um vaso de argila, coloca-se em evidência para si mesmo a obviedade da condição fugaz dessa afeição, preparando a alma para as mais diversas situações que possam envolver esse vaso. Dado que o que é material está submetido à fortuna ou ao perecimento, fica perceptível a insensatez de se considerar um bem algo que a qualquer momento pode ser perdido ou destruído. Nesse caso, atentar para o tópico do assentimento é imprescindível para que não se consinta à representação de que "ter um vaso de argila é um bem".

Além disso, o exercício de dizer para si mesmo o que as coisas realmente são inclui também dizer o que são os familiares e os indivíduos queridos, uma vez que eles também servem como objetos de representação. Diz Epicteto: "Quando beijares ternamente teu filho ou tua mulher, [diz] que beijas um ser humano, pois se morrerem, não te inquietarás"34. Por mais complicado que seja dizer isso para si mesmo, tal situação não deixa de ser verdade. Nesse caso, cabe lembrar que a morte não é um prejuízo para ninguém, nem para aquele que morre nem para aquele que fica sentido com a morte alheia, pois o único mal é aquele que pode ser cometido por si mesmo. Quando algo não depende de nós, deve ficar fora de nosso escopo de dedicação.

\footnotetext{
${ }^{33}$ ARRIANO, F. O Encheirídion de Epicteto. Edição Bilíngue. Trad. Aldo Dinucci e Alfredo Julien. São Cristóvão: Universidade Federal de Sergipe, 2012.p. 17 (III).

${ }^{34}$ ARRIANO, F. O Encheirídion de Epicteto. Edição Bilíngue. Trad. Aldo Dinucci e Alfredo Julien. São Cristóvão: Universidade Federal de Sergipe, 2012. p. 17 (III).
}

\begin{tabular}{|c|c|c|c|c|c|}
\hline intuitio & $\begin{array}{c}\text { ISSN } \\
1983-4012\end{array}$ & Porto Alegre & Vol.11 $-\mathrm{N}^{\circ} .2$ & $\begin{array}{c}\text { Dezembro } \\
2018\end{array}$ & p.17-33 \\
\hline
\end{tabular}




\section{Considerações finais}

Quando se assume que a filosofia envolve também exercício, parte-se do pressuposto que somente a elaboração teórica não é suficiente para a aquisição do conhecimento. Não se trata de forma alguma de negligenciar a teoria, mas de reconhecer que a disposição do agente de conhecimento está ela mesma inserida no processo do conhecimento. O objetivo da filosofia enquanto arte de viver bem, como Epicteto afirma ${ }^{35}$, é vivificar o conhecimento, é encarná-lo, pois o estoicismo defende que a ciência trata das coisas da vida, da natureza, sendo impossível dissociar o lógos desses dois. A áskesis na filosofia epictetiana adquire grande importância porque está associada à própria atividade de busca da sabedoria, ou seja, à própria atividade filosófica. Áskesis e filosofia são inseparáveis.

Neste artigo elencamos seis exercícios que consideramos essenciais na filosofia epictetiana, sem a pretensão de definir quantos são os exercícios propostos pelo filósofo ou de fornecer uma descrição definitiva deles. Nosso objetivo foi mostrar como os exercícios devem ser interpretados a partir do corpus teórico epictetiano, de acordo com seu vocabulário, para assim evitar possíveis anacronismos. Mostramos como o desejo, enquanto atitude racional em Epicteto demanda uma forma específica de exercício, diferente de como seria se partíssemos de uma concepção irracional do mesmo. Mostramos também como a opinião sobre o cosmos pode servir como um remédio para aspirações irracionais. Da mesma forma, indicamos a importância da atenção e da força do hábito no que diz respeito à análise das representações. Por fim, procuramos evidenciar o exercício de exposição a si mesmo, tanto por meio do que descrevemos ser uma anamnese da preferência, quanto pelo ato de dizer a si próprio a natureza das coisas.

\section{Referências}

ARRIANO, F. O Encheirídion de Epicteto. Edição Bilíngue. Trad. Aldo Dinucci e Alfredo Julien. São Cristóvão: Universidade Federal de Sergipe, 2012.

DIÔGENES LAÊRTIOS. Vidas e doutrinas dos filósofos ilustres. Trad. Mário da Gama. Brasília: Universidade de Brasília, 2008.

EPICTETO. Disertaciones por Arriano. Trad. Paloma Ortiz García. Madrid: Editorial Gredos, 1993.

EPICTETUS. The Discourses as reported by Arrian, The Manual, and Fragments. Trans. W. A. Oldfather. Londres: Heinemann, v.1, 1961.

${ }^{35}$ EPICTETO. Disertaciones por Arriano. Trad. Paloma Ortiz García. Madrid: Editorial Gredos. 1993. p. 378-379 (IV, 1, 63).

\begin{tabular}{|c|c|c|c|c|c|}
\hline intuitio & $\begin{array}{c}\text { ISSN } \\
1983-4012\end{array}$ & Porto Alegre & Vol.11 - No.2 & $\begin{array}{c}\text { Dezembro } \\
2018\end{array}$ & p.17-33 \\
\hline
\end{tabular}


EPICTETUS. The Discourses as reported by Arrian, The Manual, and Fragments. Trans. W. A. Oldfather. Londres: Heinemann, v. 2, 1952.

EPICTETUS. The Discourses of Epictetus, with the Enchiridion and Fragments. Trans. G. Long. Londres: George Bell \& Sons, 1877.

EPICURO - LUCRÉCIO - CÍCERO - SÊNECA - MARCO AURÉLIO. 3. ed. Trad. Agostinho da Silva. São Paulo: Abril Cultural, 1985. (Coleção Os Pensadores)

GILL, C. The Structured Self in Hellenistic and Roman Thought. New York: Oxford, 2006.

GROSS, D. M. The Secret History of Emotion: from Aristotle's Rhetoric to modern brain science. Chicago: The University of Chicago Press, 2006.

HADOT, P. La Ciudadela Interior. Introducción a las Meditaciones de Marco Aurelio. Trad. Maria Cucurella Miquel. Salamanca: Alpha Decay, 2013.

HADOT, P. Exercícios espirituais e filosofia antiga. Trad. Flávio Fontenelle Loque, Loraine Oliveira. São Paulo: É Realizações, 2014. (Coleção Filosofia Atual)

HADOT, P. A Filosofia como maneira de viver: entrevistas de Jeannie Carlier e Arnold I. Davidson. Trad. Lara Christina de Malimpensa. São Paulo: É Realizações, 2016.

HADOT, P. O que é filosofia antiga? Trad. Dion Davi Macedo. 6 ed. São Paulo: Loyola, 2014.

INWOOD, B. Ethics and Human Action in Early Stoicism. Oxford: Oxford University Press, 1985.

KAHN, C. Discovering the Will. In: DILLON, J. M.; LONG, A. A. (ed.). The Question of "Eclecticism": Studies in Later Greek Philosophy. Berkeley: University of California Press, 1988.

PETERS, F. E. Termos filosóficos gregos: um léxico histórico. Trad. Beatriz Rodrigues Barbosa. 2 ed. Lisboa: Fundação Calouste Gulbenkian, 1983.

PLATÓN. Carta VII. In: Diálogos VII (Dudosos, Apócrifos, Cartas). Madrid: Editorial Gredos, 1992.

RODRIGUES, A. C. O.; DINUCCI, A. A eucharistia em Epicteto. In: COSTA, C. L F.; ECCO, C.; FILHO, J. R. F. M. (Org.). Epistemologias da religião e relações de religiosidade. Curitiba: Prismas, 2017.

SEDDON, K. Epictetus' Handbook and the Tablet of Cebes: guides to Stoic living. New York: Routledge, 2005.

WOLFF, U. A Ética a Nicômaco de Aristóteles. Trad. Enio Paulo Giachini. São Paulo: Loyola, 2010.

\begin{tabular}{|c|c|c|c|c|c|}
\hline intuitio & $\begin{array}{c}\text { ISSN } \\
1983-4012\end{array}$ & Porto Alegre & Vol.11 $-\mathrm{N}^{\circ} .2$ & $\begin{array}{c}\text { Dezembro } \\
2018\end{array}$ & p.17-33 \\
\hline
\end{tabular}

